\title{
Storytelling and Sustained Silent Reading in Foreign Language Acquisition: Evidence from Taiwan
}

\author{
Sy-ying Lee \\ Professor \\ National Taipei University \\ Taiwan
}

\begin{abstract}
English education in Taiwan has been an issue for many years and the search for the core of the problem is still ongoing. What has been missing in our English education? This paper attempts to deal with several interrelated issues which are believed to be of vital importance when discussing the problem of our English education and when trying to determine ways of improving it: (1) storytelling as an indispensable first step; (2) storytelling as the bridge to independent reading; (3) extensive reading as the most enjoyable and effective means for continuing language acquisition, (4) extensive reading in the form of in-class sustained silent reading as the most important factor for developing one's academic language as well as writing ability. Finally, (5) I intend to hypothesize, with the support of research and theory, that there is a developmental path for foreign language acquisition which corresponds very well with first language development.
\end{abstract}

storytelling, extensive reading (ER), developmental path

The results released in the 2006 PIRLS (Progress in International Reading Literacy Study) showed that Taiwan has not been successful in literacy education. With an overall rank of $22^{\text {nd }}$ among the countries that participated in this study, Taiwan is below average according to many indicators, including self assessed reading ability, hours of instruction on language and reading, book collection in the school library, hours of sustained silent reading, outside of school fiction reading, outside reading for information, and outside reading for fun.

In my view, the problem is that we in Taiwan do not have a clear conception of what constitutes a successful language acquisition program and what makes literacy instruction effective. I believe this debate needs to take place within the theoretical framework of language development and second language acquisition, supported by empirical research findings. Only by scrutinizing our educational system through the lens of theory and research can we discover what has gone wrong and what can be done to remedy the situation.

\section{The Theoretical Framework}

Language acquisition theories describe how people develop their language and literacy ability. The following are very well supported by empirical evidence, and tightly interwoven with one another.

Vygotsky (1978) discussed learning on a social and collaborative base, maintaining that children require adults' scaffolding to help them reach a higher potential in their performance. 
In the context of literacy development, this claim has been elaborated by Smith's concept of The Literacy Club. Smith (1988) argues that children develop literacy by joining "The Literacy Club," the group of people who read and write. Older club members provide newer members with input, and demonstrate how literacy is used. New club members develop literacy at different rates, with no penalties.

An excellent way of inviting children to join the Literacy Club is through reading aloud to them, and telling them stories (Trelease, 2006). It has been confirmed that reading stories to children helps their language and literacy development tremendously, and it is reasonable to hypothesize that when adults read to children, the children also develop a love for reading. Chomsky (1972) argued that the best thing that adults can do to help young learners acquire language would be to expose them to a variety of language input in the form of interesting and stimulating stories.

Since an important adult role is to provide children with large quantities of input, the Comprehension Hypothesis (Krashen, 1981, 1985) is relevant here. The Comprehension Hypothesis states that we acquire language when we understand what we read and hear (Smith, 1983; Goodman, 1982). The Comprehension Hypothesis deals easily with individual differences, proposing that if input is comprehensible, all the aspects of language (grammar, vocabulary, etc) that the acquirer is developmentally ready to acquire are present in the input. Since there is considerable individual variation in rate of acquisition in the typical classroom, this means that any regular text following a strict sequential syllabus will not work. But comprehensible input will work, providing each acquirer with what he or she is ready for.

The Reading Hypothesis follows directly from the Comprehension Hypothesis, claiming that we learn to read by understanding what is on the printed page (Smith, 1983; Goodman, 1982) and that most of our competence in literacy is the result of reading (Krashen, 2004). Confirming this hypothesis are studies showing that integrating extensive reading (ER) into the regular curriculum (or sustained silent reading) has a positive effect on literacy development (Krashen, 2004). In these programs students get to read material that suits their level, they can read on their own pace, and they learn with more pleasure.

Since these two approaches in language acquisition and literacy development for native speakers of English have been well supported with empirical evidence, it is to our interest to investigate whether they also contribute to second or foreign language acquisition. It is also of interest to see if they can be combined and smoothly integrated into the regular curriculum to enhance foreign language education, in this case, English. Thus, the goal of this paper is to present research on how these two approaches, read-alouds and extensive reading, can help Taiwanese students acquire language more effectively and efficiently. In addition, an attempt will be made to draw a developmental path for EFL learners based on studies with learners of different age and educational levels. 


\section{Storytelling as the First Step to Literacy}

\section{The storytelling research}

A number of studies have confirmed the positive influence of reading aloud on different aspects of first language literacy and language development, including overall language development, vocabulary, expressive ability and verbal fluency, and even learning interests (Chomsky, 1972; Thoreson \& Dale, 1992; Ehri \& Robbins, 1994; Elley \& Mangubhai, 1983; Ewers \& Brownson, 1999; Horner, 2004; Justice, 2002; Lomax, 1977; Snow \& Ninio, 1986; Senechal, 1997; Valdez-Menchaca \& Whitehurst, 1992). Fewer studies have been done focusing on how read-alouds affect children acquiring English as a foreign/second language.

Among the few studies that show the impact of storytelling on English as a foreign language, a handful were written in Mandarin and published in Taiwan. Subjects in these studies were third to sixth graders - children who had some basic knowledge of English, and had greater background knowledge than younger children. These studies were mostly qualitative, examining how children improved in learning interest, motivation and attitude, such as being more active in interacting with the teacher or asking more questions (Chien \& Huang, 1999; Hsieh, 1998; Tien \& Shen, 2003; Tso, 2003).

Only two studies investigated how kindergarten EFL children developed the concept of reading through stories read to them. One of the studies (Chien \& Huang, 1999) used The Emergent Reading Behavior Inventory (a modified version of Goodman, 1982) to investigate if children behaved differently after a year of storytelling. Researchers found that children made significant progress in concepts about print, e.g. book awareness, print direction, print awareness, suggesting that children can develop print awareness through literacy activities before formal reading instruction begins. Miscue analysis results also suggested that children could use the graphic-phonemic connection to read unknown words without being taught phonics.

\section{Storytelling in an EFL class for more than three years}

While most of the studies mentioned above were short-term, lasting a year or less, a three and a half year longitudinal qualitative study using storytelling in an after-school program in Taiwan has provided a great deal more information (Wang \& Lee, 2007). The goal of the study was to determine how time could be better spent in class and how children grew in language and learning attitude, as well as how these pupils developed into independent readers, given lots of stories, reading materials, and time to read.

Ten $4^{\text {th }}$ graders participated in the program. Seven joined the project at the beginning, in 
grade one, and three more joined in grade 2. All students came to class with little to some experience in learning English. Those with some learning experience had had instruction on the alphabet and some phonics, and some exposure to songs and games in their English class, which in Taiwan, is for two 40 minute periods per week in grades one and two.

The students attended a 90-minute session of English class each day, two days a week. The first 40 minutes were devoted to traditional instruction in reading, vocabulary and grammar, and practice in dialogues, an approach expected by the children's parents who sent them to the after-school program.

The core activity of the second half of the class, also 40 minutes, was reading aloud to the children with accompanying activities, including songs, chants, rhymes, poems, and drama.

The instructor noticed that the children occasionally used words that they had clearly acquired from the stories they heard. For example, children could use expressions such as "Oh, you're gross! You're so disgusting!" at the right moment; these expression were clearly from Marvin Redpost.

\section{Storytelling as the Bridge to Self Reading}

Marvin Redpost, a series of chapter books about a 9-year old boy, was introduced in the third year of this class after more than two years of picture book reading. These books were chosen due to the stories being relevant to these children's life experience and their match to their cognitive maturity.

A ten-minute sustained silent reading period was introduced in the fourth year of the program, which the children used to read books from the Marvin Redpost series. The read-aloud activity, according to Trelease (2006), had served as a promotion to and a natural partner with reading.

Because of individual variation in level of English competence among the students, the teacher still provided picture books for use during the SSR time and would give a brief introduction about the storybooks that students might be interested in reading on their own (please see http://web.ntpu.edu.tw/ lwen/readinglab.html for Effie's Classroom for more information).

Creating autonomous readers is the ultimate goal of language education. Storytelling in this study successfully brought the pupils to the stage of enthusiastic independent reading.

We believe it requires a substantial amount of time for story listeners to become readers, as we saw in this study. If this development can be seen in such a classroom outside of the regular school curriculum, there is no doubt that we can do even more to help improve our foreign language education during school hours: More funding can be obtained for purchasing books, more time can be spent on meaningful storytelling, book talks, and in-class SSR. If we 
make this modest investment, more competent readers will be created, with better reading comprehension, writing ability and larger vocabularies, as the research shows.

\section{Extensive Reading and Foreign Language Acquisition}

\section{Extensive reading research in $L 1$}

Studies consistently show that children who grow up in a print-rich environment display superior competence in several different aspects of language and literacy, including syntax, vocabulary, spelling, and knowledge of history, culture, literature, and practical information (Cipielewski and Stanovich 1990, 1992; Chomsky 1972; Goodman 1982; Nagy, Herman, and Anderson 1985; Nagy, Anderson, and Herman 1987; Shu, Anderson, and Zhang 1995; Stanovich and Cunningham 1992; West, Stanovich and Mitchell 1993).

The impact of reading exposure on one's first language development has also been found for Mandarin in a survey study I did in 1995. I found that the richness of the print environment (indicated by parental education, parents' reading behavior, parents' view toward reading, and number of books owned in the home) was a significant predictor of Taiwanese senior high school students' free reading behavior, which in turn was the only significant predictor among others (leisure writing and writing apprehension) of subjects' Chinese writing performance on a nation-wide entrance examination (Lee, 1995).

\section{Extensive reading survey studies in L2}

In addition to my L1 study of Taiwanese senior high school students, my survey study with EFL university students also came to the same conclusion: Free reading was the only significant predictor among others (writing anxiety, writer's block, free writing frequency, attitude toward instruction) of students' English writing ability (Lee, 2005). It was also found that the amount of free reading done could be at least part of the cure for the learner's fear of writing in English and that those who read more possess better composing strategies.

A number of other studies found that free voluntary reading or recreational reading was associated with ESL learners' writing ability (Gradman \& Hanania, 1991; Huang, 1996; Janopoulos, 1986) and performance on TOEFL (Constantino, Lee, Cho, \& Krashen, 1997; Gradman \& Hanania, 1991). These results have clear pedagogical implications for foreign language education.

\section{In-Class Sustained Silent Reading}

\section{Empirical studies on in-class ER/SSR}


Experiments have shown that extensive reading in an SSR class, with no direct instruction on formal aspects of language, has been shown to be very effective for children, teenagers, and college students in acquiring a second or foreign language (Cho and Krashen 1994; Cho, 1995; Cho and Kim 2004; Elley and Mangubhai 1983; Elley 1980, 1989, 1991; Hafiz and Tudor 1990; Lai 1993; Lao and Krashen 2000; Mason and Krashen 1997; Mason 2003; McQuillan 1994; Tsang 1996; Tudor and Hafiz 1989; Young 2001). More important, extensive reading is very pleasant to do and promotes a life-long approach to language acquisition and intellectual growth (Krashen 2004).

In recent years, there has been a plethora of research in Taiwan investigating the potential of extensive reading as the core element in class for English teaching. This research has shown that students participating in sustained silent reading make gains that are equivalent to or better than gains made by comparison students in classes not including SSR, in reading and vocabulary (Cheng 2003; Hsu \& Lee 2005; Hsu \& Lee, 2007; Lee, 2007; Sheu 2004; Sims 1996; Yuan \& Nash 1992), writing (Lee \& Hsu 2007; Hsu \& Lee, 2007), grammar (Sheu 2004), and attitudes toward reading (Lee 1998; Sheu 2004). However, all of these studies were short-term with no follow-up to confirm the effectiveness of in-class SSR.

I present here a brief description of three consecutive studies done with Taiwanese university students, with each study an improved version of the previous one (please see Lee, 2007 , for details).

\section{What do we learn from the three consecutive studies?}

Study I. The first study lasted for one semester and examined the impact of ER under less-than-optimal conditions: Students read for only 12 weeks, had access to a limited amount of reading (215 graded readers), were asked to write summaries of what they read, and their in-class reading was done only once a week. The study took place in the second half of a year-long course; the first semester was devoted to viewing films with Chinese subtitles and was taught by another teacher. The results of the pretests revealed not only students' significantly lower proficiency level before treatment, but might also reflect their low motivation in learning English.

Two comparison groups were used. Comparison group 1 used a textbook and did traditional reading comprehension and writing exercises. In comparison group 2, outside reading was encouraged, but no record of the reading was kept. In addition, the instructor of group 2 devoted about 70 to $80 \%$ of class-time to explaining vocabulary students encountered in the assigned text as well as related words. Neither comparison class did grammatical analysis or form-focused exercises. Both included discussion of culture, role-plays, discussions, and presentations, as well as direct teaching of reading strategies and vocabulary. 
Results (Table 1) showed that the reading group did slightly better than the first comparison group on the vocabulary test, but the difference was not significant $(p=.32)$. Comparison 2 did better than the reading group, and the difference fell just short of statistical significance $(\mathrm{p}=.07)$. On a cloze test, a measure of reading comprehension, the reading group gained just as much as Comparison group 2 without formal instruction.

Table 1. Vocabulary Test Results

\begin{tabular}{|c|c|c|c|c|c|c|c|c|c|}
\hline & 2000 & & 3000 & & 5000 & & & CLOZE & \\
\hline & Pre/post & gain & Pre/post & gain & Pre/post & gain & $\begin{array}{l}\text { Total } \\
\text { gain }\end{array}$ & Pre/post & gain \\
\hline $\begin{array}{l}\text { Exp. } \\
\text { (S.D.) }\end{array}$ & $\begin{array}{c}41.4 / 45.2 \\
(9.9) /(8.1) \\
\end{array}$ & 3.8 & $\begin{array}{c}32.8 /(35.6) \\
(12.2) /(11.2) \\
\end{array}$ & 2.8 & $\begin{array}{c}22.2 / 25.3 \\
(10.1) /(9.8) \\
\end{array}$ & 3.1 & 9.7 & $\begin{array}{c}37.9 / 44 \\
(12) /(11.5) \\
\end{array}$ & 5.6 \\
\hline $\begin{array}{l}\text { Com. } 1 \\
\text { (S.D.) }\end{array}$ & $\begin{array}{c}47.6 / 49.1 \\
(8.5) /(7.8) \\
\end{array}$ & 1.5 & $\begin{array}{c}41.5 / 42.1 \\
(12.7) /(12.0) \\
\end{array}$ & 0.6 & $\begin{array}{c}31 / 33.2 \\
(12.0) /(12.4) \\
\end{array}$ & 2.2 & 4.3 & $\begin{array}{c}44 / 45 \\
(13) /(12.6) \\
\end{array}$ & 1.0 \\
\hline $\begin{array}{l}\text { Com. } 2 \\
\text { (S.D.) }\end{array}$ & $\begin{array}{l}49.2 / 50.7 \\
(4.7) /(3.6)\end{array}$ & 1.5 & $\begin{array}{l}42.0 / 45.1 \\
(8.5) /(7.1)\end{array}$ & 3.1 & $\begin{array}{c}29.3 / 34.4 \\
(11.0) /(8.8)\end{array}$ & 5.2 & 9.8 & $\begin{array}{c}46.3 / 51.3 \\
(11.4) /(10.4)\end{array}$ & 5.0 \\
\hline
\end{tabular}

Note. The vocabulary level tests were taken from Nation (1990), the cloze from Mason (2003)

Study II. In this study, some of the flaws of Study 1 were repaired. All groups had equivalent levels of English competence at the start of the treatment and the treatment lasted one academic year. In this study, three comparison classes (Com $1=40$; Com $2=45$; Com $3=54$ ), randomly selected from the 26 Freshman English classes at the same university, and one experimental class $(\mathrm{N}=67)$ taught by the researcher were involved, and all four groups were similar on all pretests.

The experimental group had the same treatment as those in the previous study, but with a larger book collection, 570 graded reader titles. The comparison groups had textbook-oriented instruction, reading, analyzing and discussing texts, student presentations based on issues related to the assigned readings, and direct instruction on language skills and learning strategies covered in the text. There were also regular quizzes and examinations. The vocabulary measure developed by Schmitt (2000) replaced the Nation measure used in Study I. Schmitt's measure was used to assess 2000, 3000, 5000, 10,000 and academic level words.

During the second semester, students were required to read five texts: Stuart Little, Charlotte's Web, The Trumpet of the Swan, The Little Prince, and Tuesdays with Morrie. In addition, students were required to choose another two books from a list of suggested readings. The list consisted of books related to current popular films, such as The Bridges of Madison County, Bridget Jones' Diary and books from the Harry Potter series, as well as teachers' suggestions.

Table 2. Gain Scores for the Vocabulary and Cloze Tests

\begin{tabular}{|c|c|c|c|c|}
\hline & \multicolumn{2}{|c|}{ DIFF pre/post } & \multirow[b]{2}{*}{$\mathrm{t}$} & \multirow[b]{2}{*}{$\mathrm{p}$} \\
\hline & COMP & EXP & & \\
\hline 2000 & 0.6 & 1.6 & 2.01 & 0.046 \\
\hline
\end{tabular}




\begin{tabular}{ccccc}
\hline 3000 & 1.4 & 3.1 & 2.72 & $0.007^{*}$ \\
5000 & 1.9 & 3.5 & 2.55 & 0.012 \\
10000 & 1.4 & 3.6 & 3.84 & $0.00013^{*}$ \\
ACADEMIC & 1.8 & 2.7 & 0.55 & 0.583 \\
TOTAL & 7.3 & 14.4 & 4.35 & $0.000014^{*}$ \\
CLOZE & 4.9 & 5 & 0.01 & 0.99 \\
\hline
\end{tabular}

This study resulted in a modest victory for the group that did self-selected reading followed by assigned reading over traditional instruction in vocabulary growth, and a tie in reading comprehension, as measured by the cloze test (Table 2). A likely candidate for the unimpressive results on the cloze tests is the kind of books that were assigned. The list consisted of books that teachers felt were interesting; teachers' views, however, may not be the same as students' views (Ujiie and Krashen 2002). In fact, some students remarked that they merely flipped through the pages of the assigned books, with little comprehension, and several students considered E.B. White's books too childish. With such a lack of enthusiasm about the reading, in fact, one wonders how the students made as much progress as they did.

Study III. The purpose of this study was to compare another version of SSR - a full year of self selected reading - with assigned reading. In this study, the comparison groups used in study II were combined to form one comparison group, since the measures used and the duration of instruction were the same. Subjects in the experimental group (Exp 2, N = 41) did self-selected reading, choosing from a collection of about 1200 titles for one academic year. Experimental group 1 was the assigned reading group from the previous study, presented here again to facilitate comparison.

Table3. Means and Standard Deviations on Gains

\begin{tabular}{ccccccccc}
\hline Groups & & D2000 & D3000 & D5000 & D10000 & DACADE & DTOTAL & DCLOZE \\
\hline Com & Mean & .66 & 1.5 & 2.0 & 1.4 & 1.8 & 7.2 & 4.6 \\
& SD & 2.5 & 4.1 & 4.4 & 3.8 & 4.8 & 11.3 & 6.7 \\
Exp 1 & Mean & 1.6 & 3.1 & 3.5 & 3.6 & 2.6 & 14.4 & 5.0 \\
assigned & SD & 4.0 & 3.8 & 3.6 & 4.1 & 4.8 & 10.8 & 7.6 \\
Exp 2 & Mean & 1.3 & 4.2 & 4.4 & 4.3 & 2.9 & 17.0 & 14.6 \\
Self-selected & SD & 3.1 & 4.5 & 3.2 & 3.3 & 4.1 & 11.1 & 7.4 \\
\hline
\end{tabular}

Table 4. Multiple Comparisons with Scheffe Post Hoc Test on Gain Scores

\begin{tabular}{llcccc}
\hline & (I) GROUP & (J) GROUP & $\begin{array}{c}\text { Mean Difference } \\
(\mathrm{I}-\mathrm{J})\end{array}$ & Std. Error & Sig. \\
\hline \multirow{2}{*}{ D2000 } & Com & Exp1 & -.8879 & .4705 & .17 \\
& Com & Exp2 & -.5878 & .5689 & .59 \\
& Exp1 & Exp2 & .3000 & .6222 & .89 \\
\hline D3000 & Com & Exp1 & -1.6830 & .6185 & $.03^{*}$ \\
& Com & Exp2 & -2.7324 & .7478 & $.00^{*}$ \\
& Exp1 & Exp2 & -1.0494 & .8180 & .44 \\
\hline \multirow{2}{*}{ 55000 } & Com & Exp1 & -1.6613 & .5873 & $.02^{*}$ \\
& Com & Exp2 & -2.3291 & .7102 & $.01^{*}$ \\
& Exp1 & Exp2 & -.6678 & .7768 & .69 \\
\hline D10000 & Com & Exp1 & -2.1937 & .5708 & $.00^{*}$ \\
& Com & Exp2 & -2.7911 & .6902 & $.00^{*}$
\end{tabular}




\begin{tabular}{llllll} 
& Exp1 & Exp2 & -.5974 & .7549 & .73 \\
\hline DACADE & Com & Exp1 & -.8335 & .7082 & .50 \\
& Com & Exp2 & -.7194 & .8564 & .70 \\
& Exp1 & Exp2 & .1140 & .9367 & .99 \\
\hline DTOTAL & Com & Exp1 & -7.2593 & 1.6283 & $.00^{*}$ \\
& Com & Exp2 & -9.1598 & 1.9689 & $.00^{*}$ \\
\hline DCLOZE & Exp1 & Exp2 & -1.9005 & 2.1536 & .68 \\
\hline & Com & Exp1 & -.3687 & 1.0817 & .94 \\
& Com & Exp2 & -9.9542 & 1.3080 & $.00^{*}$ \\
& Exp1 & Exp2 & -9.5855 & 1.4307 & $.00^{*}$ \\
\hline
\end{tabular}

Note. The mean difference is significant at the .05 level.

Results shown in Tables 3 and 4 indicated that Experimental groups 1 and 2 (assigned SSR and self-selected SSR) significantly outperformed the combined comparison group on the 3000, 5000, 10,000 vocabulary level tests. As in Study II, there was no significant difference among the groups in the gains on academic level words, although both experimental groups made slightly better gains than comparisons in raw scores. As for the cloze test, the self-selected reading group (Exp 2) performed significantly better than the comparison groups combined and also outperformed the experimental group that did assigned reading in Study II (Exp 1).

This result confirms the importance of fully respecting students' free selection of materials, a practice that gives them the responsibility for their own learning and enhances their motivation to read. Students' logs confirmed the benefits of self-selection. While students in Experimental Group 1 found E.B. White boring, the Experimental Group 2 students' choices were "so interesting and fun to read."

This series of studies was intended to contribute to providing a more solid basis for the design of SSR programs for EFL students. The results provide a response to some of the concerns and doubts some might have about integrating extensive reading into the curriculum. First, the longer the duration, the better the results. Second, the criticism that extensive reading "takes time," and we need to accelerate students' acquisition of English through more systematic instruction and output practice on the underlying sub-skills and learning strategies has been answered. Mason's study (2003) also found that more writing practice does not help with writing ability. Finally, without formal instruction, the reading group made the same gains as comparisons on academic level words.

\section{Implication: A Developmental Path}

From the L1 research established so far, we can observe a clear developmental path for L1 speakers' language acquisition from being read to in their early childhood to free voluntary reading for pleasure and a higher level use of the language. The idea of using storytelling as the first step in introducing a new language is rarely found in the ELF professional literature. According to my own observations, the main component of instruction 
in the elementary English classroom in Taiwan is instruction on the rules of phonics and letter-sound correspondences and memorization of vocabulary, supplemented with games and dialogues that do not really match children's interests nor meet their needs. Rules can be abstract, boring and confusing to EFL children when no comprehensible, compelling, and meaningful input is supplied. According to Smith (2003), “... both boredom and confusion are aversive; they are not natural states to be in" (p. 6). There is no reason for this: EFL children do not have any "urgent need" to acquire English. The only motivation that works for them is fun and pleasure.

The three year exploratory study in the after-school program reported above tells us that it is possible to teach EFL children with little or zero English background by using storytelling. These children began to do independent reading after two or three years of read-alouds, just as L1 children develop language following this natural route.

If these children are able to read chapter books in grade 4 , they will be able to do more reading in their junior high, senior high, and college years, as long as reading material is made available for in-class SSR.

From the studies I conducted with university students, I found that most students found even low-level graded readers difficult, readers containing 300 to 3000 headwords. This was the case even though all had memorized up to 7000 English words in preparation for the college entrance examination. This fact suggests that if words are not acquired through meaningful contexts, they are not retained, and the time spent in memorization has not been worthwhile (Krashen, 2002).

There is obviously an obstacle for EFL learners on their journey of English language acquisition; it is not because they started late, but because they started with the wrong approach. The developmental path for EFL learners should correspond with first language development, starting with reading lots of stories, moving on to longer texts such as chapter books, providing more abundant materials for self-selected reading, and allowing time especially devoted to self-selected reading.

Revisiting the results from PIRLS and the studies presented in this paper, I have come to the conclusion that "no instruction" is better than "poor instruction." Bad English classes leave a bitter taste forever. And the harder we try to force English down children's throats, the worse the situation gets. Just as Plato wisely put it, "Compulsory physical exercise does no harm to the body, but compulsory learning never sticks in the mind." (The Republic, Part VIII, book 7, pages 269-270, translated by Desmond Lee, London: Penguin, second edition, 1974). 


\section{References}

Cheng, C. K. (2003). Extensive reading, word guessing strategies, and incidental vocabulary acquisition. Selected Papers from the Twelfth International Symposium on English Teaching (pp. 188-198). Taipei: Crane.

Chien, Y. C., \& Huang, Y. K. (1999). Starting with predictable stories: EFL children's oral and literacy development. The Proceedings of the Ninth International Conference on English Teaching (pp. 264-273). Taipei: Crane.

Cho, K. S., \& Kim, H. J. (2004). Recreational reading in English as a foreign language in Korea: Positive effects of a 16-week program. Knowledge Quest, 36-38.

Cho, K. S., \& Krashen, S. (1994). Acquisition of vocabulary from the Sweet Valley High Kids series: Adult ESL acquisition. Journal of Reading, 37, 662-667

Cho, K. S., \& Krashen, S. (1995). From Sweet Valley Kids to Harlequins in one year. California English, 1, 18-19.

Chomsky, C. (1972). Stages in language development and reading exposure. Harvard Educational Review, 42, 1-33.

Cipielewski, J., \& Stanovich, K.E. (1992). Predicting growth in reading ability from children's exposure to print. Journal of Experimental Child Psychology, 54, 74-89.

Constantino, R., Lee, S. Y., Cho, K. S., Krashen, S. (1997). Free voluntary reading as a predictor of TOEFL scores. Applied Language Learning, 8(1), 111-118.

Ehri, L. C, \& Robbins, C. (1994). Reading storybooks to kindergarteners helps them learn new vocabulary words. Journal of Educational Psychology, 86 (1), 54-64.

Elley, W. (1980). A comparison of content-interest and structuralist reading programs in Niue Primany schools. New Zealand Journal of Educational Studies, 15(1), 39-53.

Elley, W. (1989). Vocabulary acquisition from listening to stories. Reading Research Quarterly, 24(2), 174-187

Elley, W. (1991). Acquiring literacy in a second language: The effects of book-based programs. Language Learning, 41, 375-411.

Elley, W., \& Mangubhai, E. (1983). The impact of reading on second language learning. Reading Research Quarterly, 19, 53-67.

Ewers. C. A., \& Brownson, S. M. (1999). Kindergarteners' vocabulary acquisition as a function of active vs. passive storybook reading, prior vocabulary, and working memory . Journal of Reading Psychology, 20, 11-20.

Goodman, K. (1982). Language and literacy: The selected writings of Kenneth S. Goodman. 2 vols. Ed. F. Gollasch. London: Routledge.

Gradman, H. L., \& Hanania, E. (1991). Language learning background factors and ESL proficiency. The Modern Language Journal, 75, 39-51. 
Hafiz, F. M., \& Tudor, L. (1990). Extensive reading and the development of language skills. ELT Journal, 43, 4-11.

Horner, S. L. (2004). Observational learning during shared book reading: The effects on preschoolers' attention to print and letter knowledge. Reading Psychology, 25, 167-188.

Hsieh, L. T. (1998). Simple but effective: reading aloud in EFL reading. Studies in English Language and Literature, 3, 19-30.

Hsu, Y. Y., \& Lee, S. Y. (in press). Extensive reading and EFL junior college in Taiwan. Studies of English Language and Literature, 20. (NSC94-2411-H-305-004)

Hsu, Y. Y., \& Lee, S. Y. (2007). A Three-Year Longitudinal Study on In-Class Sustained Silent Reading with Taiwanese Junior College Students: Its Effects, Practice, and Difficulties. Selected Papers from The Sixteen International Symposium on English Teaching (pp. 620-624). Taipei: Crane.

Huang, I. C. (1996). The relationship of free reading and writing proficiency in second language acquisition. Proceedings of the $13^{\text {th }}$ ROC TEFL (pp. 133-143). Taipei: Crane.

Janopoulos, M. (1986). The relationship of pleasure reading and second language writing proficiency. TESOL Quarterly, 20, 763-768.

Justice, L. M. (2002). Word exposure conditions and preschoolers' novel word learning during shared storybook reading. Reading Psychology, 23, 87-106.

Krashen, S. (1981). Second language acquisition and second language learning. Elmsford, NY: Pergamon Press.

Krashen, S. (1985). The input hypothesis: Issues and implications. Culver City, CA: Language Education Associates.

Krashen, S. (1993). The Power of Reading. Englewood, CO: Libraries Unlimited

Krashen, S. (2002). Explorations in Language Acquisition and Use: Taipei Lecture. Taipei: Crane.

Krashen, S. (2004). The Power of Reading. ( $2^{\text {nd }}$ Ed.). Portsmouth, NH: Heinemann.

Lai, F. K. (1993). The effect of a summer reading course on reading and writing skills. System, 21(1), 87-100.

Lao, C.Y., \& Krashen, S. (2000). The impact of popular literature study on literacy development in EFL: More evidence for the power of reading. System, 28, 261-270.

Lee, S. Y. (2007). Revelations from Three Consecutive Studies on Extensive Reading. Regional Language Center (RELC) Journal, 38(2), 150-170. Singapore.

Lee, S. Y. (2005). Facilitating and inhibiting factors on EFL writing: A model testing with SEM. Language Learning, 55(2), p. 335-374 (NSC89-2411-H-305-002)

Lee, S. Y. (1998). Effects of introducing pleasure reading and language acquisition theory on students' attitudes toward the English class. Studies in English Language and Literature, 4, 21-28.

Lee, S. Y. (1995). A cross-cultural validation of The Reading Hypothesis: The relationship of 
pleasure reading to writing proficiency and academic achievement among Taiwanese senior high school students. Doctoral dissertation, University of Southern California, Los Angeles, CA., U.S.A.

Lee, S. Y., \& Hsu, Y. Y. (2007). Does extensive reading work with vocational college students? Proceedings of 2007 International Conference and Workshop on TEFL \& Applied Linguistics (pp. 659-662).

Lomax, C. L. (1977) Interest in books and stories at nursery school. Educational Research, 19, 100-112.

Mason, B. (2003). Sufficiency of extensive reading on the development of grammatical accuracy. Doctoral dissertation, Temple University, Tokyo.

Mason, B., \& Krashen, S. (1997). Extensive reading in English as a foreign language. System, 25, 91-102.

McQuillan, J. (1994). 'Reading versus grammar: What students think is pleasurable for language acquisition', Applied Language Learning, 5, 95-100.

Nagy, W., Anderson, R., \& Herman, P. (1987). Learning words from context during normal reading. American Educational Research Journal, 24, 237-270.

Nagy, W., Herman, P., \& Anderson, R. (1985). Learning words from context. Reading Research Quarterly, 20, 233-253.

Nation, P. (1990). Teaching and learning vocabulary (NY: Newbury House Publishers).

Schmitt, N. (2000). Vocabulary in Language Teaching (Cambridge: Cambridge University Press).

Senechal, M. (1997). The differential effect of storybook reading on preschoolers' acquisition of expressive and receptive vocabulary. Cambridge University Press, 24, 123-138.

Sheu, S. P-H. (2004). Extensive reading with EFL learners at beginning level. TESL Reporter, 36(2), 8-26.

Shu, H., Anderson, R. C., \& Zhang, H. (1995). Incidental learning of word meanings while reading; A Chinese and American cross-cultural study. Reading Research Quarterly, 30(1), 76-95.

Sims, J. (1996). A new perspective: Extensive reading for pleasure. The Proceedings of the Fifth International Symposium on English Teaching, pp. 137-144.

Smith, F. (1983). Essays into Literacy. Portsmouth, NH: Heinemann.

Smith, F. (1988). Joining the literacy club. Victoria, B.C.: Abel Press.

Smith, F. (2003). Unspeakable acts, unnatural practices: Flaws and fallacies in scientific reading instruction. Portsmouth, $\mathrm{NH}$ : Heinemann .

Snow, C. E., \& Ninio, A. (1986). The contracts of literacy: What children learn from listening to read books. In W. H. Teale, \& E. Sulzby (Eds.), Emergent literacy: Writing and Reading (pp.116-138). Norwood, NJ: Ablex.

Stanovich, K., \& Cunningham, A. (1992). Studying the consequences of literacy within a 
literate society: the cognitive correlates of print exposure. Memory and Cognition, 20(1), 51-68.

Thoreson, C. C., \& Dale, P. S. (1992). Do early talkers become early readers? Linguistic precocity, preschool language, and emergent literacy. Developmental Psychology, 28, 421-429.

Tien, N-C., \& Shen, I-P. (2003). Elementary school homeroom teachers utilizing children's English literatures to assist students' English learning: An action research study. Selected Papers from the Twelfth International Symposium on English Teaching and Learning (pp. 559-569). Taipei: Crane.

Trelease, J. (2006). The read-aloud handbook. $5^{\text {th }}$ rev. ed. New York: Penguin.

Tsang, W. K. (1996). Comparing the effects of reading and writing on writing performance. Applied Linguistics, 17(2), 210-233.

Tso, W-L (2003). Storytelling as English language learning in primary school. Journal of Taiwan Normal University, 48(1), 53-67.

Tudor, I., \& Hafiz, F. (1989). Extensive reading as a means of input to L2 learning. Journal of Research in Reading, 12(2), 164-178.

Ujiie, J., \& Krashen, S. (2002). 'Home Run Books and Reading Enjoyment', Knowledge Quest 31(1), 36-37.

Valdez-Menchaca, M. C., \& Whitehurst, G. J. (1992). Accelerating language development through picture book reading: A systematic extension to Mexican day care. Developmental Psychology, 28, 1106-1114.

Vygotsky, L. S. (1978). Mind in Society. Cambridge. Mass.: Harvard University Press.

Wang, F.Y., \& Lee, S.Y. (2007). From listeners to readers with storytelling to bridge the gap. Selected Papers from the Sixteenth International Symposium on English Teaching (pp. 545-555). Taiwan: Crane.

West, R., K., Stanovich, K., \& Mitchell1, H. (1993). 'Reading in the real world and its correlates', Reading Research Quarterly 28, 35-50.

Young, A. (2001). Reading and the non-academic learner: A mystery solved. System, 29(4), 451-66.

Yuan, Y. P., \& Nash, T. (1992). Reading subskills and quantity reading. Selected papers from The Eighth Conference on English Teaching and Learning in the Republic of China (pp. 291-304). Taipei: Crane. 